\title{
Trypanocidal constituents in plants. 7. Mammea-type coumarins
}

\author{
Ricardo Reyes-Chilpa/ ${ }^{+}$, Elizabeth Estrada-Muñiz ${ }^{1}$, Elisa Vega-Avila², Fumiko Abe ${ }^{3}$, Junei Kinjo ${ }^{3}$, \\ Simón Hernández-Ortega
}

Instituto de Química, Universidad Nacional Autónoma de México, Circuito Exterior, Ciudad Universitaria, México, 04510 DF, México ${ }^{1}$ Sección Externa de Toxicologia, CINVESTAV-IPN, México, DF, México ${ }^{2}$ Departamento de Ciencias de la Salud, Universidad Autónoma Metropolitana, México, DF, México ${ }^{3}$ Faculty of Pharmaceutical Sciences, Fukuoka University, Fukuoka, Japan

Calophyllum brasiliense and Mammea americana (Clusiaceae) are two trees from the tropical rain forests of the American continent. A previous screening showed high trypanocidal activity in the extracts of these species. Several mammea-type coumarins, triterpenoids and biflavonoids were isolated from the leaves of $\mathrm{C}$. brasiliense. Mammea A/ AA was obtained from the fruit peels of $\mathrm{M}$. americana. These compounds were tested in vitro against epimastigotes and trypomastigotes of Trypanosoma cruzi, the etiologic agent of Chagas disease. The most potent compounds were mammea $A / B A, A / B B, A / A A, A / B D$ and $B / B A$, with $M C_{100}$ values in the range of 15 to $90 \mu \mathrm{g} / \mathrm{ml}$. Coumarins with a cyclized $\gamma, \gamma$-dimethylallyl substituent on $C-6$, such as mammea $B / B A$, cyclo $F+B / B B$ cyclo $F$, and isomammeigin, showed $M C_{100}$ values $>200 \mu \mathrm{g} / \mathrm{ml}$. Several active coumarins were also tested against normal human lymphocytes in vitro, which showed that mammea A/AA and A/BA were not toxic. Other compounds from C. brasiliense, such as the triterpenoids, friedelin, canophyllol, the biflavonoid amentoflavone, and protocatechuic and shikimic acids, were inactive against the epimastigotes. The isopropylidenedioxy derivative of shikimic acid was inactive, and its structure was confirmed by X-ray diffraction. Our results suggest that mammea-type coumarins could be a valuable source of trypanocidal compounds.

Key words: Trypanosoma cruzi - Calophyllum brasiliense - Mammea americana - coumarins - Chagas disease

The protozoan Trypanosoma cruzi is the etiological agent of Chagas disease (American trypanosomiasis), which affects 16-18 million people in Latin America and is responsible for the deaths of more than $45,000 \mathrm{pa}-$ tients per year (WHO 1997). It is transmitted to humans by triatomine bugs or through infected blood transfusions (Pizzolatti et al. 2002). The life cycle of $T$. cruzi is complex, and it alternates between vertebrate and invertebrate hosts. When the triatomine bug is feeding on human blood, it defecates and releases metacyclic trypomastigotes near the bite wound. This infective agent is capable of reaching intracellular locations and transforming into amastigotes. After reproduction, the amastigotes turn back into trypomastigotes, and the cells burst. The released parasites can either infect other cells or be consumed by other triatomine bugs. In the intestine of an invertebrate host, the blood trypomastigotes transform into epimastigotes, which divide and give rise to infective metacyclic-trypomastigotes (Brener 1973, Contreras et al. 2002).

Medication for Chagas disease is usually effective when given during the acute stage of infection. Once the disease has progressed to later stages, no medication has proven to be completely effective. Moreover, synthetic drugs such as nifurtimox, a 5-nitrofuran, and

+ Corresponding author: chilpa@servidor.unam.mx

Received 20 March 2008

Accepted 21 July 2008 benznidazole, a 2-nitro-imidazole (Lampit $\AA$, Bayer, and Rochagan $\AA$, Roche, respectively) are used for the treatment of this disease. Unfortunately, both drugs have limited efficacy during the chronic phase of the disease and present several undesirable side effects (Gutteridge 1985, Umezawa et al. 2001, Coura \& Castro 2002). Chemoprophylatic measures against Chagas disease are scarce, present variable efficacy, or are not adopted due to their costs. Currently, gentian violet is used to sterilize blood banks in endemic areas (Pizzolatti et al. 2002, Coura \& Castro 2002). An urgent need to develop new drugs exists, and natural products can provide useful drug leads as well as the scientific basis for the rational use of medicinal plants.

Calophyllum brasiliense Camb. is a large tree, measuring up to $40 \mathrm{~m}$ in height, from the tropical rain forest. It is distributed throughout Latin America, from Brazil to Mexico, and is used in folk medicine. In Mexico, its most common name is bari, and the infusion of the cortex is consumed by women over nine days for "cleaning" the womb after child-birth, while the seeds provide an oil used for lighting and for healing skin afflictions (Soto \& Sousa 1995). In Colombia, the peasants call this tree $a r$ bol de aceite (oil tree), and the yellow latex exuded from the cortex is applied topically for healing the navels of newborn children (García-Barriga 1992). In Brazil, it is known as guanandi, and has been used in folk medicine for the treatment of rheumatism, varicose hemorrhoids and chronic ulcers (Corrêa 1978). In the Amazon basin, the bark infusion is used by the Karaja ethnic group for the treatment of diarrhea, and in Guyana, C. brasiliense is mixed with Coutarea hexandra to treat diabetes and worms (Mesía-Vela et al. 2001). 
C. brasiliense heartwood contains xanthones with trypanocidal (Abe et al. 2002) and antifungal (ReyesChilpa et al. 1997) properties. The methanol extract from the leaves contains hyperin (hyperoside), amentoflavone, quercetin, gallic acid and protocatechuic acid (da Silva et al. 2001). The analysis of the hexane extracts of the leaves has demonstrated the existence of two chemotypes of $C$. brasiliense in Mexico. Only the organic extracts from $C$. brasiliense chemotype 1 showed trypanocidal activity during preliminary screening (Abe et al. 2002). The leaves of this chemotype contain mammea-type coumarins that were cytotoxic to human tumor cells in vitro (Reyes-Chilpa et al. 2004). The mixture of two of these coumarins, mammea A/BA and A/ $\mathrm{BB}$, was better than vincristine at inhibiting the growth of implanted tumors in mice (Ruiz-Marcial et al. 2007). The leaves of chemotype 2 contain chromanones and triterpenoids as the major constituents, and tetracyclic dipyranocoumarins in low concentrations, which inhibit the reverse transcriptase of the human immunodeficiency virus type 1 in vitro (Huerta-Reyes et al. 2004). It has recently been reported that (-) -mammea $\mathrm{A} / \mathrm{BB}$ from the leaves of $C$. brasiliense showed potent activity against the promastigote and amastigote forms of Leishmania (L.) amazonensis (Brenzan et al. 2007). Mammea $\mathrm{A} / \mathrm{BB}$ is also known to be molluscicidal against Biomphalaria glabrata (Gasparotto et al. 2005).

Mammea americana $\mathrm{L}$. is a tree measuring up to $20 \mathrm{~m}$ in height from the tropical rain forest. Its original distribution was through the Antilles Islands and South America, but it was presumably introduced into Mexico after the Spanish colonization in the XVI century. In Cuetzalan, state of Puebla, Mexico, its edible fruits are called zapote domingo, and the tree is grown by peasants in their backyards (Martínez-Alfaro et al. 1995). In Colombia, the fruits are known as mamey, and the powder of the seeds is spread or dissolved in water to form an emulsion used as a topical insecticide on dogs and humans for eliminating fleas, lice, and mange mites (García Barriga 1992). Thirty-nine mammea-type coumarins have been previously isolated and identified from most organs of M. americana (Yang et al. 2006). The related species M. africana is used in Nigerian traditional medicine for the treatment of malaria fever. Schizontosidal activity has been demonstrated from the ethanolic stem bark extract in mice infected with Plasmodium berghei berghei (Okodon et al. 2006).

In six previous reports, we have presented results on the trypanocidal activity of natural compounds obtained from plant species belonging to different families (Abe et al. 2006). In the case of Clusiaceae species from the American continent, we have identified several active compounds, such as xanthones from $C$. brasiliense heartwood and benzophenones from Garcinia intermedia leaves (Abe et al. 2004). We have also detected high trypanocidal activity in the organic extracts of the leaves of C. brasiliense (chemotype 1), and the peels of the fruits of M. americana (Abe et al. 2002). In the present paper, we continue our studies in this area by investigating the trypanocidal activity of the main compounds present in these extracts.

\section{SUBJECTS, MATERIALS AND METHODS}

Plant material - C. brasiliense was collected at the Ejido Benigno Mendoza, Sierra de Santa Marta, state of Veracruz, Mexico. A voucher specimen was deposited with the number 435-Bojórquez et al. in the Herbarium of the Instituto de Investigaciones Biológicas, Universidad Veracruzana in Xalapa, Mexico. M. americana fruits were obtained from Catemaco, state of Veracruz, Mexico. A voucher with the registry number IMSSM 14420 was deposited in the Herbarium of the Instituto Mexicano del Seguro Social in Mexico City.

Isolation of compounds from the leaves of C. brasiliense - Compounds 1-13 (Fig. 1) were obtained after column chromatography on Silica Gel-60 (CC) from the hexane, acetone, and methanol extracts of the leaves of C. brasiliense (chemotype 1) as previously described (Reyes-Chilpa et al. 2004). Identification was done by ${ }^{1} \mathrm{H}$ NMR, ${ }^{13} \mathrm{C}$ NMR, IR, UV, EIMS and CIMS, and comparison with published data (Crombie et al. 1967a, b, Reyes-Chilpa et al. 2004). The yield of mammea coumarins was estimated as $1.5 \%$ of the leaves' dry weight. The separation of a mixture of mammea A/BA (3), A/ BB (4) and A/BD (5) (4.0 g) was achieved by HPLC using an ODS column eluting with $90 \% \mathrm{MeOH}$. Part of the acetone extract $(5.3 \mathrm{~g})$ was subjected to CC elution with mixtures of hexane-ethyl acetate (4:6 to 1:9), which delivered colourless crystals $(49.8 \mathrm{mg})$ that were recrystallized in acetone-hexane (1:4) and identified as the 3,4-isopropylidenedioxy derivative of shikimic acid (12). This compound has been previously isolated from the buds of Mammea longifolia. Its ${ }^{1} \mathrm{H}$ and ${ }^{13} \mathrm{C}$ NMR spectra were similar to those previously reported (Rao et al. 2002). Its structure was confirmed by X-ray crystallography (Figs 2, 3).

Spectral data of compound $12-\mathrm{C}_{10} \mathrm{H}_{14} \mathrm{O}_{5}$, colourless crystals, mp 170-172 ${ }^{\circ} \mathrm{C}$. IR $(\mathrm{KBr}) \mathrm{cm}^{-1}: 3339(\mathrm{OH}) ; 1701$ $(\mathrm{C}=\mathrm{O}) ; 1644(\mathrm{C}=\mathrm{C}) ; 1276(\mathrm{C}-\mathrm{O})$. EMIE: $70 \mathrm{ev}, \mathrm{m} / \mathrm{z}$ (\%): $214 \mathrm{M}^{+}(0.5 \%)\left[\mathrm{C}_{10} \mathrm{H}_{14} \mathrm{O}_{5}\right] ; 199(100 \%)\left[\mathrm{M}^{+}-\mathrm{CH}_{3}\right]$; $139(51.77 \%)$.

$X$-ray structure analysis summary of compound 12 Crystal data: $\mathrm{C}_{10} \mathrm{H}_{14} \mathrm{O}_{5}$, Crystal system Orthorombic $\mathrm{P} 2$ 2,2 , cell parameters $\mathrm{a}=5.7250(1), \mathrm{b}=6.0100(1), \mathrm{c}=$ 31.356(6) $\AA, \mathrm{z}=4, \mathrm{~V}=1078.9(3) \AA^{3}, \mathrm{M}_{\mathrm{r}}=214.21 \mathrm{D}_{\text {calc }}$ $=1.319 \mathrm{Mg} / \mathrm{m}^{3}, \mu=0.106 \mathrm{~mm}^{-1}, \mathrm{~F}(000)=456$. A crystal of dimensions of $0.40 \times 0.30 \times 0.40 \mathrm{~mm}$ was mounted on a SIEMENS P4/PC diffractometer, using MoK $\alpha$ radiation $\left(\lambda=0.71073 \AA\right.$ ), a $\omega$ scan range of 2.60 to $24.98^{\circ}$ and an index range of $0 \leq h \leq 6,0 \leq k \leq 7,0 \leq 1 \leq 37$. There were 1,182 collected reflections and 576 observed reflections $[\mathrm{I}>2 \sigma(\mathrm{I})]$. The structure was solved by direct methods using the SHELXS program, and 143 parameters were refined by a full-matrix least-squares method with the SHELXTL-2000 program with positional and anisotropic thermal parameter factors for non-H atoms. Hydrogen atoms were placed in calculated positions using Uiso $=1.2$ times of the preceding atoms. $\mathrm{H}$ atoms on $\mathrm{O} 1$ and O5 were located on the difference Fourier map, and refined isotropically. The final values were $\mathrm{R}=0.0494, w \mathrm{R}$ $=0.0801, \mathrm{GOF}=0.811$, and the largest different peak and hole were $0.179 /-0.190 \mathrm{e} . \AA^{-3}$. The scattering factor was 


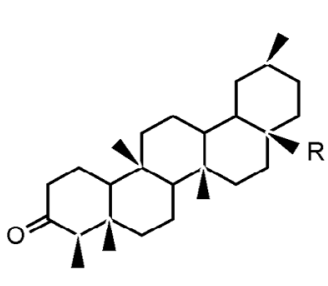

(1) $\mathrm{R}=\mathrm{Me}$

(2) $\mathrm{R}=\mathrm{CH}_{2} \mathrm{OH}$<smiles>[R]c1c(O)c(CC=C(C)C)c(O)c2c(CCC)cc(=O)oc12</smiles>

(6) R= 少

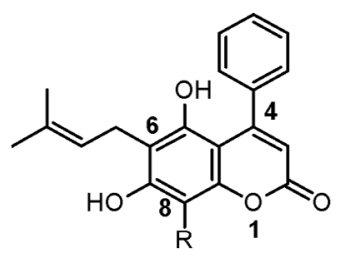

(3) $R=\underbrace{\frac{0}{\mu}}_{0}$<smiles>CCC(C)C(O)=CC=[18O]</smiles>

(5) $\mathrm{R}$<smiles>[R]C=C(C(=O)[R]=[R])C(C)CC</smiles><smiles>O=c1cc(-c2ccc(O)c(-c3c(O)cc(O)c4c(=O)cc(-c5ccc(O)cc5)oc34)c2)oc2cc(O)cc(O)c12</smiles>

(9)<smiles>O=C(O)c1ccc(O)c(O)c1</smiles>

(11)<smiles>CC1(C)OC2C=C(C(=O)O)CC(O)C2O1</smiles>

(12)<smiles>CC(C)CC(=O)c1c(O)c2c(c3c(-c4ccccc4)cc(=O)oc13)OC(C)(C)C=C2</smiles>

(10)<smiles>O=C(O)C1=CC(O)C(O)C(O)C1</smiles>

(13)<smiles>CC(C)=CCc1c(O)c(C(=O)CC(C)C)c(O)c2c(-c3ccccc3)cc(=O)oc12</smiles>

(14)

Fig. 1: compounds isolated from C. brasiliense (1-13), and M. americana (14) (names of compounds in Tables I and II).

taken from International Tables for X-ray Crystallography (Hahn 1983). Supplementary data for compound 12 has been deposited at the Cambridge Crystallographic Data Centre. Copies of this information are available free of charge on request (http://www.ccd.cam.ac.uk) quoting the deposit numbers CCDC 697638.

Isolation of mammea $A / A A$ - The peels $(421.0 \mathrm{~g})$ from fruits of $M$. americana were dried, ground and extracted with hexane at room temperature (r.t.). The extract spontaneously afforded a yellow crystalline compound (6.22 g), which was recrystallized from hexane- $\mathrm{CH}_{2} \mathrm{Cl}_{2}$. The compound was identified from its spectroscopic data as mammea A/AA (14), which was previously isolated from the seeds of this species (Crombie et al. 1967b). The yield of compound 14 was $1.47 \%$ on a dry weight basis.

Cultivation of T. cruzi - The strain of T. cruzi used in this study was H6 (International code: MHOM/GT/95/ SMI-06). The epimastigotes of T. cruzi were cultured in liver infusion tryptose (LIT) medium (Difco) as previously described (Baum et al. 1981). Hemin was replaced by hemoglobin (Japan Biotest Intitute). The trypomastigotes were harvested from the culture supernatant of rhesus monkey kidney (LLC-MK2) cells infected with T. cruzi (Hiyama et al. 2001). LLC-MK2 cells were maintained in Dulbecco's modified Eagle's medium (DMEM, Sigma) containing 10\% fetal bovine serum (FBS, Gibco). After inoculation of trypomastigotes into LLC-MK2 cells, the medium was changed to DMEM containing 10\% newborn calf serum (Nacalai Tesque).

Assay of trypanocidal activity - Each compound was dissolved in dimethylsulfoxide (DMSO, Sigma) and diluted with LIT medium to obtain the desired concentration. The final DMSO concentration was less than $0.05 \%$. One percent of DMSO solution itself caused no effect on the survival of the epimastigotes. Fifty microliters of each cell suspension $\left(\sim 2 \times 10^{6}\right.$ epimastigotes $\left./ \mathrm{ml}\right)$ and sample solution were placed in 96-well microplates in duplicate by a serial two-fold dilution method and incubated at $26^{\circ} \mathrm{C}$ for $48 \mathrm{~h}$. The control was sample free. The motion of the epimastigotes in both the sample and the control wells was observed under an inverted light microscope $(100 \mathrm{X})$. Each test was assayed twice. The sample solutions used against the trypomastigotes were prepared in the same way using DMEM instead of the LIT medium. Fifty microliters of each sample solution and cell suspension $\left(\sim 1 \times 10^{6}\right.$ trypomastigotes $\left./ \mathrm{ml}\right)$ were placed in 96-well microplates in duplicate and incubated at $37^{\circ} \mathrm{C}$ for $48 \mathrm{~h}$ under a $5 \% \mathrm{CO}_{2}$ atmosphere. Berberine chloride (Tokyo Chemical Industries Co. Ltd.) was used as a positive control, since it has shown strong activity against trypomastigotes in previous reports (Abe et al. 2002 , 2004). The activity was assessed as a $\mathrm{MC}_{100}$ value, which was defined as the minimum concentration at which all of the epimastigotes or trypomastigotes died after a 48 h-incubation (Abet et al. 2002). The results are shown in Tables I and II.

Human lymphocyte isolation - Heparanized blood was taken from a nonsmoking, 24 year-old healthy man who had not taken any medication for at least 15 days before the blood donation. Written consent was obtained from the donor. The lymphocytes were isolated as previously described (Böyum 1968). Briefly, following collection, the blood was diluted (1:2) in phosphate buffered saline (PBS), layered on hystopaque-1077 (Hystopaque-1077; Sigma Diagnostics, St. Louis, USA) and centrifuged for $30 \mathrm{~min}$ at $400 \mathrm{~g}$ at r.t. Peripheral blood mononuclear cells (a mixture of monocytes and lymphocytes) were collected from the interphase, washed once with PBS and resuspended in RPMI 1640 medium (in vitro, Mexico) supplemented with 10\% FBS (Gibco) and $2 \mathrm{mM}$ glutamine at a concentration of $5 \times 10^{6}$ cells $/ \mathrm{ml}$. 


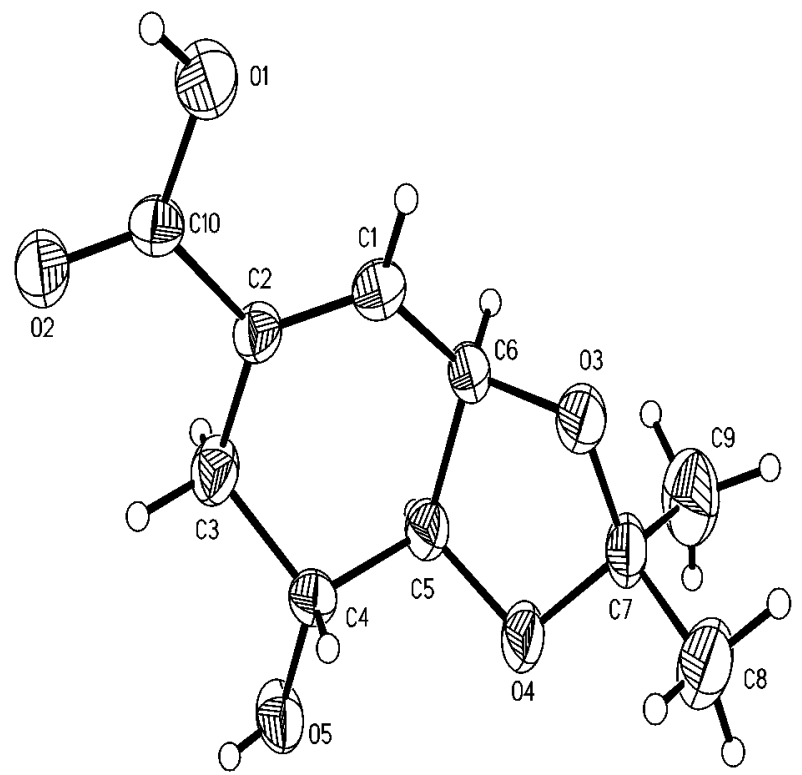

Fig. 2: X-ray crystallographic structure of 3,4-isopropylidine derivative of shikimic acid (12).

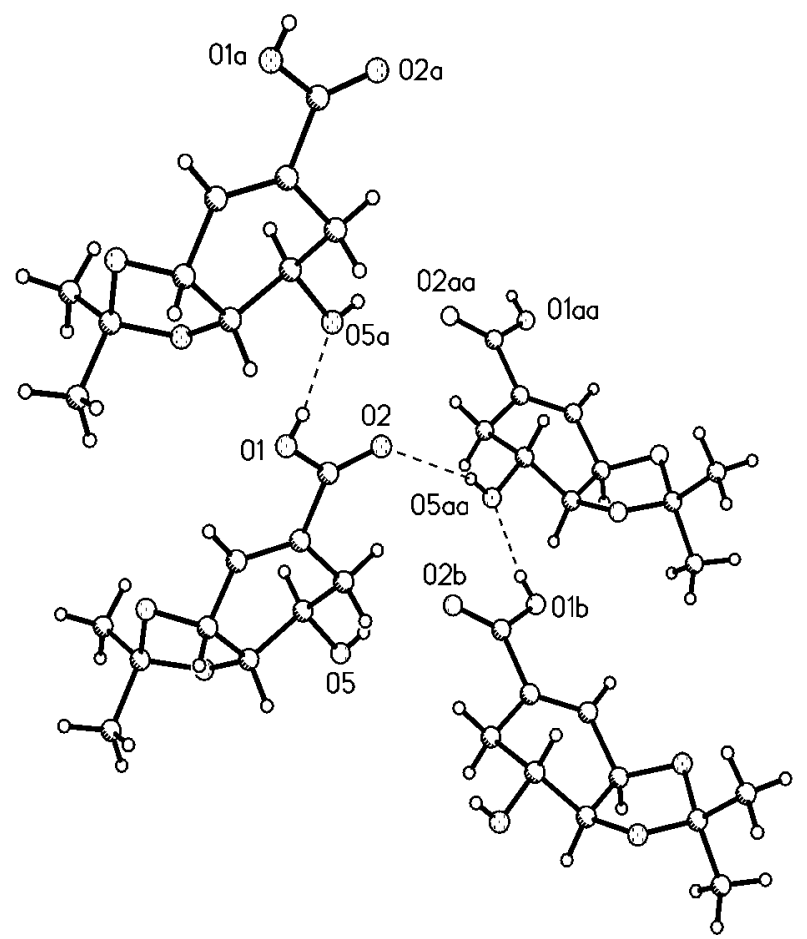

Fig. 3: crystal packing of compound 12.

Cytotoxic assay - Each compound was first dissolved in DMSO and then diluted with RPMI medium to obtain the desired concentration. One hundred microliters of the lymphocyte cell suspension was placed in 96-well microplates $\left(5 \times 10^{5}\right.$ cells/well). Phytohemaglutinin (final concentration: $2 \%$ ) was added to the cells and they were further incubated at $37^{\circ} \mathrm{C}$ for $24 \mathrm{~h}$ under a $5 \% \mathrm{CO}_{2}$ atmosphere. Following, $100 \mu \mathrm{l}$ of each compound solu- tion was added to the final concentrations ranging from 0.01 to $500 \mu \mathrm{g} / \mathrm{ml}$. The control only received the same amount of vehicle. The final DMSO concentration was kept constant at $0.1 \%$ and lymphocyte viability was evaluated by the MTT assay (Mosman 1983). The formazan product was measured at $550 \mathrm{~nm}$ using a multiplate reader (Spectra Count, Packard, Canada) and the drug effect was assessed as $\mathrm{LC}_{50}$ and $\mathrm{LC}_{100}$ values, which represent the drug concentration that inhibits $50 \%$ and $100 \%$ of cellular growth, respectively. Each test was assayed in triplicate. The selectivity index (SI) was obtained, and is represented as the $\mathrm{LC}_{100} / \mathrm{MC}_{100}$ relation.

\section{RESULTS}

Several mammea-type coumarins with a phenyl substituent on C-4 (series A/: $3,4,5,10$ ) as well as a propyl chain on $\mathrm{C}-4$ (series $\mathrm{B} /: \mathrm{6}, 7,8$ ) were isolated from the leaves of $C$. brasiliense. The mammea A/AA (14) was isolated from the peel of the fruit of M. americana (Fig. 1). The coumarins were harmful to epimastigotes and trypomastigotes of $T$. cruzi (Table I). In general, mammea coumarins showed higher activity against epimastigotes than trypomastigotes, and those with uncyclized C-6 prenyl chains were more potent. The highest activity was shown by mammea B/BA (6) $\left(\mathrm{MC}_{100}=15\right.$ and $25 \mu \mathrm{g} / \mathrm{ml}$, respectively), followed by mammea $\mathrm{A} / \mathrm{BA}$ (3), $\mathrm{A} / \mathrm{BB}$ (4), A/AA (14) and mammea A/BD (5). Coumarins with cyclized prenyl substituents on $\mathrm{C}-6$, such as the mixture of mammea B/BA cyclo $\mathrm{F}+\mathrm{B} / \mathrm{BB}$ cyclo $\mathrm{F}(7,8)$ and mammea A/BA cyclo D (isomammeigin, 10), were less active against both stages of $T$. cruzi with $\mathrm{MC}_{100}$ values $>200 \mu \mathrm{g} / \mathrm{ml}$. In contrast to mammea coumarins, the positive control, berberine chloride, was more potent against trypomastigotes than epimastigotes $\left(\mathrm{MC}_{100}=7\right.$ and $300 \mu \mathrm{g} / \mathrm{ml}$, respectively, Table I). In the former case, it was at least three times more potent than the best of the coumarins, mammea $\mathrm{B} / \mathrm{BA}$.

The toxicity of several mammea coumarins on normal human lymphocyte cultures was also investigated (Tables I, II). Mammea A/AA, A/BA, and the mixture of mammea $\mathrm{B} / \mathrm{BA}$ cyclo $\mathrm{F}$ and $\mathrm{B} / \mathrm{BB}$ cyclo $\mathrm{F}$ did not show toxicity, and demonstrated an $\mathrm{LC}_{100}$ range between $120.5-301.1 \mu \mathrm{g} / \mathrm{ml}$. Therefore, the SI to trypomastigotes was 2.41-8.95 (Table I).

Other compounds isolated from the leaves of $C$. brasiliense, such as protocatechuic acid (11), shikimic acid (13), and the 3,4-isopropylidine derivative of shikimic acid (12), showed poor activity $\left(\mathrm{MC}_{100}>500 \mu \mathrm{g} / \mathrm{ml}\right)$ against epimastigotes of $T$. cruzi. Due to these initial screens, their activity against trypomastigotes was not investigated any further. The biflavonoid amentoflavone (9), as well as the triterpenoids friedelin (1) and canophyllol (2), were inactive against epimastigotes $\left(\mathrm{MC}_{100}>\right.$ $1000 \mu \mathrm{g} / \mathrm{ml}$ ) (Table II).

Compound 12 has only been isolated from the buds of M. longifolia (Rao et al. 2002), and could be a taxonomical marker for the Mammea genus; therefore, it was important to confirm its structure by X-ray crystallography (Fig. 2). The sterodiagram indicates that the compound in the crystal is joined by intramolecular hydrogen bonds, O5-H5A---O2 and O1-H---O5 (Fig. 3). 
TABLE I

Trypanocidal and cytotoxic activity of coumarins from C. brasiliense and M. americana

\begin{tabular}{|c|c|c|c|c|c|c|}
\hline Compound & $\begin{array}{c}\mathrm{MC}_{100} \mu \mathrm{g} / \mathrm{ml} \\
\mathrm{Epi}\end{array}$ & $\begin{array}{c}\mathrm{MC}_{100} \mu \mathrm{g} / \mathrm{ml} \\
\text { Try }\end{array}$ & $\mathrm{LC}_{50} \mu \mathrm{g} / \mathrm{ml}$ & $\mathrm{LC}_{100} \mu \mathrm{g} / \mathrm{ml}$ & $\begin{array}{c}\mathrm{SI} \mathrm{LC}_{100} / \mathrm{MC}_{100} \\
\text { Epi }\end{array}$ & $\begin{array}{c}\mathrm{SI} \mathrm{LC}_{100} / \mathrm{MC}_{100} \\
\text { Try }\end{array}$ \\
\hline Mammea A/BA (3) & 15 & 30 & 50.51 & 126.45 & 8.43 & 4.21 \\
\hline Mammea A/BB (4) & 25 & 25 & ND & ND & & \\
\hline Mammea A/BD (5) & 30 & 90 & ND & ND & & \\
\hline Mammea B/BA (6) & 15 & 25 & 168.16 & 223.78 & 14.91 & 8.95 \\
\hline $\begin{array}{l}\text { Mammea B/BA cyclo F \& B/BB } \\
\text { cyclo F (7 \& 8) }\end{array}$ & $>200$ & $>200$ & 135.64 & 301.10 & & \\
\hline Mammea A/BA cyclo D (10) & 200 & $>200$ & ND & ND & & \\
\hline Mammea A/AA (14) & 35 & 50 & 56.64 & 120.50 & 3.44 & 2.41 \\
\hline Berberine cloride $^{a}$ & 300 & 7 & 36.53 & 284.4 & 0.94 & 40.62 \\
\hline
\end{tabular}

$a$ : positive control; Epi: epimastigotes; Try: trypomastigotes; HL: human lymphocytes; ND: not done.

TABLE II

Trypanocidal and cytotoxic activity of miscellaneous compounds from C. brasiliense

\begin{tabular}{lcc}
\hline Compound & $\mathrm{MC}_{100} \mu \mathrm{g} / \mathrm{ml}$ & $\mathrm{LC}_{50} \mu \mathrm{g} / \mathrm{ml}$ \\
\cline { 2 - 3 } & $\mathrm{Epi}$ & $\mathrm{HL}$ \\
\hline Friedelin (1) & $>1000$ & $>500$ \\
Canophyllol (2) & $>1000$ & $>500$ \\
Amentoflavone (9) & $>1000$ & $\mathrm{ND}$ \\
Protocatechuic acid (11) & $>500$ & $\mathrm{ND}$ \\
3,4-isopropylidine derivative & & \\
of shikimic acid (12) & $>500$ & $\mathrm{ND}$ \\
Shikimic acid (13) & $>500$ & $>500$ \\
\hline
\end{tabular}

ND: not done; Epi: epimastigotes; HL: human lymphocytes.

\section{DISCUSSION}

To the best of our knowledge this is the first report on the trypanocidal activity of mammea-type coumarins. Several of these compounds were active against epimastigotes and trypomastigotes of $T$. cruzi, showing low cytotoxicity to normal human lymphocytes in vitro. For example, mammea B/BA (6) and mammea A/BA (3) showed a SI of 8.95 and 4.21 against the trypomastigotes, respectively (Table I). Similar results have been obtained with other protozoan species. It has been reported that (-) mammea A/BB (4) is toxic to L. amazonensis, but not to J774G8 murine macrophages in vitro, showing a SI of 8.6 for promastigotes and 29.3 for amastigotes. (Brenzan et al. 2007). Concerning acute mammal toxicity in vivo, a preliminary report indicated that a mixture of mammea $\mathrm{A} / \mathrm{BA}$ and $\mathrm{A} / \mathrm{BB}$ administered intra peritoneally was innocuous to mice in a dose range of $2-3500 \mathrm{mg} / \mathrm{Kg}$ (Ruiz-Marcial 2005). Sub-acute toxicity for the mixture of mammea $\mathrm{A} / \mathrm{BA}$ and $\mathrm{A} / \mathrm{BB}$ was also investigated in mice at a dose of $20 \mathrm{mg} / \mathrm{Kg}$ administered i.p. every third day during one month. No mortality and no visible signs of toxicity, such as allopesia, tremor, or hair stiffness, was observed after this period. Afterwards, the mice were sacrificed and histological and macroscopic observations were carried out on the liver, kidney, spleen and thymus without detecting noticeable changes when compared with untreated mice (Ruiz-Marcial 2005).
The mechanism of action of the mammea coumarins against epimastigotes and trypomastigotes of $T$. cruzi remains unknown. However, the available evidence suggests that these compounds may affect mitochondria and mitosis. (-)-Mammea A/BB (4) caused ultrastructural changes of the promastigotes of L. amazonensis, especially in the mitochondrial matrix, inducing the appearance of binucleate cells and multiple cytoplasm vacuolization (Brenzan et al. 2007). It is known that mammea A/BA (3), A/BB (4), B/BA (6) and A/AA (14) are uncouplers of oxidative phosphorylation at concentrations $<0.5 \mathrm{mg} / \mathrm{ml}$ (Crombie et al. 1972). It has also been reported that the mixture of mammea A/BA (3) and A/BB (4) inhibited the division of baby mouse kidney cells in vitro, arresting them in the S-phase of the cell cycle (Ruiz-Marcial et al. 2007).

Our results indicate that mammea coumarins can be obtained in good yield from C. brasiliense leaves (1.5\%) and $M$. americana fruit peels $(1.47 \%)$, and suggests that these species could be appropriate for sustainable management in Latin America. In this context, a recent analysis of $M$. americana grown in Florida, USA, showed that mammea coumarins are present in all plant organs. The ten main coumarins of the seeds, mammea E/BD, $\mathrm{E} / \mathrm{BC}, \mathrm{E} / \mathrm{BA}, \mathrm{E} / \mathrm{BB}, \mathrm{B} / \mathrm{BA}$ hydroxycyclo $\mathrm{F}, \mathrm{B} / \mathrm{BD}, \mathrm{B} /$ $\mathrm{BC}, \mathrm{B} / \mathrm{BA}(6), \mathrm{B} / \mathrm{BB}$, and $\mathrm{B} / \mathrm{BA}$ cyclo $\mathrm{F}(7)$, were quantified by HPLC, and the highest concentration (w/w \%) was found in the roots $(0.75 \%)$, followed by the leaves $(0.64 \%)$ (Yang et al. 2006). The edible fruits of M. americana could be investigated as possible chemopreventive agents for Chagas disease and other ailments, since they also contain mammea coumarins $(<0.01 \%)$. Finally, the control of triatomid bugs, the vectors of $T$. cruzi, can also be explored since several mammea coumarins bearing a 1-acetoxypropyl chain on C-4 (series E), such as mammea $\mathrm{E} / \mathrm{BA}$ and $\mathrm{E} / \mathrm{BB}$, show remarkable insecticidal properties (Crombie et al. 1972).

\section{ACKNOWLEDGEMENTS}

To of Dr. Hiroshige Akahane and Dr. Miguel Angel Martínez-Alfaro (In memoriam), friends and colleagues, which participated in this project, to the editorial staff and reviewers for their help in improving the manuscript, Dr. Manuel Jiménez, for technical advice, Dr. Mario Vásquez-Torres and Biol. 
Laura Cortéz-Zárraga, for assistance with plant collection, identification and access to BADEPLAM-UNAM data base, and Dr. Margaret Lee, from Universidad Autónoma Metropolitana, for style revision.

\section{REFERENCES}

Abe F, Nagafuji S, Okabe H, Akahane H, Estrada-Muñiz E, HuertaReyes M, Reyes-Chilpa R 2004. Trypanocidal constituents in plants 3. Leaves of Garcinia intermedia and heartwood of Callophyllum brasiliense. Biol Pharm Bull 27: 141-143.

Abe F, Nagafuji S, Okawa M, Kinjo J 2006. Trypanocidal constituents in plants 6. Minor withanolides from the aerial parts of Physalis angulata. Chem Pharm Bull 54: 1226-1228.

Abe F, Nagafuji S, Yamauchi T, Okabe H, Maki J, Higo H, Akahane H, Aguilar A, Jiménez-Estrada M, Reyes-Chilpa R 2002. Trypanocidal constituents in plants 1 . Evaluation of some Mexican plants for their trypanocidal activity and active constituents in guaco, roots of Aristolochia taliscana. Biol Pharm Bull 25: 1188-1191.

Baum SG, Wittner M, Jeffrey PN, Nadler JP, Horwitz, SB, Denis JE, Schiff PB, Tanowitz HB 1981. Taxol, a microtubule stabilizing agent, blocks the replication of Trypanosoma cruzi. Proc Natl Acad Sci USA 78: 4571-4575.

Böyum A 1968. Isolation of mononuclear cells and granulocytes from human blood. Isolation of monuclear cells by one centrifugation, and of granulocytes by combining centrifugation and sedimentation at 1 g. Scand J Clin Lab Invest 97 (Suppl.): 77-89.

Brener Z 1973. Biology of Trypanosoma cruzi. Annu Rev Microbiol 27: $347-382$.

Brenzan MA, Nakamura CV, Prado Dias Filho B, Ueda-Nakamura T, Young M CM, Aparício Garcia Cortez D 2007. Antileishmanial activity of crude extract and coumarin from Calophyllum brasiliense leaves against Leishmania amazonensis. Parasitol Res 101: 715-722.

Contreras VT, Navarro MC, de Lima AR, Artega R, Duran F, Askue J, Franco Y 2002. Production of amastigotes from metacyclic trypomastigotes of Trypanosoma cruzi. Mem Inst Oswaldo Cruz 97: 1213-1220.

Corrêa MP 1978. Calophyllum brasiliense. In Dicionário das plantas úteis do Brasil e das exóticas cultivadas, Vol. 3, Imprensa Nacional, Rio de Janeiro, 388 pp.

Coura JR, Castro SL de A 2002. Critical review on Chagas disease chemotherapy. Mem Inst Oswaldo Cruz 97: 3-24.

Crombie L, Games DE, Haskins NJ, Reed GF 1972. Extractives of Mammea americana L. Part V. The insecticidal compounds. $J$ Chem Soc [Perkin 1]: 2255-2260.

Crombie L, Games DE, McCormick 1967a. Extractives of Mammea americana L. Part I The 4-n-alkylcoumarins. Isolation and structure of mammea B/BA, B/BB, B/BC, and C/BB. J Chem Soc 7: $2545-2552$.

Crombie L, Games DE, McCormick 1967b. Extractives of Mammea americana L. Part II. The 4-phenylcoumarins. Isolation and structure of mammea A/AA, A/A cyclo D, A/BA, A/AB and A/ BB. J Chem Soc 7: 2553-2559.

Da Silva KL, dos Santos AR, Mattos PE, Yunes RA, Delle-Monache F, Cechinel-Filho V 2001. Chemical composition and analgesic activity of Calophyllum brasiliense leaves. Therapie 56: 431-434.

García-Barriga H 1992. Flora Medicinal de Colombia, Vol. 2, 2nd ed., Tercer Mundo Editores, Bogotá, Colombia, 537 pp.

Gasparotto Jr. A, Brenzan MA, Piloto IC, Nakamura CV, Prado Dias Filho B, Rodrigues Filho E, Ferreira AG 2005. Phytochemical study and evaluation of the molluscicidal activity of Calophyllum brasiliense Camb (Clusiaceae). Quim Nova 28: 575-578.

Gutteridge WE 1985. Existing chemotherapy and its limitations. $\mathrm{Br}$ Med Bull 41: 162-168.

Hahn T (ed.) 1983. International Tables for X-Ray Crystallography, Vol. A, The International Union of Crystallography, D Reidel Publ Co, Dordrecht, 854 pp.

Hiyama K, Hamano S, Nakakura T, Nomoto K, Tada I 2001. IL-4 reduces resistance of mice to Trypanosoma cruzi. Parasitol Res 87: 269-274.

Huerta-Reyes M, Basualdo MC, Abe F, Jiménez-Estrada M, Soler C, Reyes-Chilpa R 2004. Anti HIV-1 compounds of Calophyllum brasiliense leaves. Biol Pharm Bull 27: 1471-1475.

Martínez-Alfaro MA, Evangelista V, Mendoza M, Morales G, Toledo G, Wong A 1995. Catálogo de plantas útiles de la Sierra Norte de Puebla, México. Cuadernos del Instituto de Biología, Vol. 27, Universidad Nacional Autónoma de México, México, 303 pp.

Mesía-Vela S, Sánchez RI, Estrada-Muñiz E, Alavez-Solano D, Torres-Sosa C, Jiménez-Estrada M, Reyes-Chilpa R, Kauffman FC 2001. Natural products isolated from Mexican medicinal plants, novel inhibitors of sulfotransferases SULTIA 1 and SULT1A and SULT2A. Phytomedicine 8: 481-488.

Mosmann T 1983. Rapid colorimetric assay for cellular growth and survival: application to proliferation and cytotoxicity assays. $J$ Immunol Methods 65: 55-63.

Okokon JE, Udokpoh AE, Essiet GE 2006. Antimalarial activity of Mammea africana. African J Trad Compl Alt Med 3: 43-49.

Pizzolatti MG, Koga AH, Grisard EC, Steindel M 2002. Trypanocidal activity of extracts from Brazilian Atlantic rain forest plant species. Phytomedicine 9: 422-426.

Rao LJM, Yada H, Ono H, Yoshida M 2002. Acylated and non-acylated flavonol monoglycosides from the Indian minor spice nagkesar (Mammea longifolia). J Agric Food Chem 50: 3143-3146.

Reyes-Chilpa R, Estrada-Muñiz E, Ramírez AT, Amekraz B, Aumelas A, Jankowski CK, Vázquez-Torres M 2004. Cytotoxic effects of mammea type coumarins from Calophyllum brasiliense. Life Sci 75: 1635-1647.

Reyes-Chilpa R, Jiménez-Estrada M, Estrada-Muñiz E 1997. Antifungal xanthones from Calophyllum brasiliensis heartwood. $J$ Chem Ecol 23: 1901-1911.

Ruiz-Marcial CA 2005. Estudio farmacológico y toxicológico de las coumarinas aisladas de Calophyllum brasiliense sobre la tumorigénesis experimental, MSc Thesis, Universidad Autónoma del Estado de Morelos, Cuernavaca, México, 107 pp.

Ruiz-Marcial CA, Reyes-Chilpa R, Estrada E, Reyes-Esparza J, Garrido-Fariña G, Rodríguez-Fragoso L 2007. Antiproliferative, cytotoxic and antitumor activity of coumarins isolated from $\mathrm{Ca}$ lophyllum brasiliense. J Pharm Pharmacol 59: 719-725.

Soto JC, Sousa M 1995. Plantas Medicinales de la Cuenca del Río Balsas. Cuadernos del Instituto de Biología, Vol. 25, Universidad Nacional Autónoma de México, México, 198 pp.

Umezawa ES, Stolf AMS, Corbett CEP, Shikanai-Yasuda MA 2001. Chagas' disease. Lancet 357: 797-799.

WHO - World Health Organization 1997. Chagas' disease. Thirteenth Programme Report UNDP/WB/TDR, Geneve, Switzerland, p. 112-123.

Yang H, Jiang B, Reynertson KA, Basile MJ, Kennelly EJ 2006. Comparative analysis of bioactive mammea coumarins from seven parts of Mammea Americana by HPLC-PDA with LC-MS. J Agric Food Chem 54: 4114-4120. 